\title{
Strategic Plan For Societal Peace And Development In Islam
}

\author{
A. A. Akanni, PhD \\ Department of Religious Studies \\ Olabisi Onabanjo University \\ Ago-Iwoye, Nigeria
}

\begin{abstract}
One of the good things that distinguish the modern society from the primitive one is the ability to plan for the future. This affects all aspects of human life. In today's world, man plans for everything- his family, his cities and even the future of the world. Hence, today, one hears of family planning, development plan and strategic plan. The planning is purposely meant to enhance qualitative standard of living for all by setting specific goals to be achieved possibly within specific periods as well as step by step means of achieving those goals. It is in that spirit that the Millennium Development Goals (MDGs) as well as the Sustainable Development Goals (SDGs) both of which aimed at an effective system of global mobilization to achieve a set of imperative social priorities worldwide within specific periods were developed. Islam, which claims to address all issues on the one hand and also, claims to be a natural religion that is in tandem with human nature on the other hand amazingly also has within its structure, a strategic plan for everything! In this paper, Islam's strategic plan for societal peace and development is examined with a view to drawing the attention of the world to it for the benefit of the human race on the one hand and on the other, to showcase the beauty of Islam as a civilized religion that envisioned man needs for all ages.
\end{abstract}

Keywords: strategic plan, society, peace, development, Islam

\section{INTRODUCTION}

Planning is a practice that has come to be identified with the modern human society. The man plans everything about himself; he plans his life, plans his family, plans his town, plans his country and with others even jointly plans the future of the world he lives in. This comes in various forms and under various terminologies. It is either a short-term or a long term planning. He uses terms such as family planning, town planning, development plan, strategic plan among others to describe each of the areas that he directs his planning towards. The essence of the planning in each case is to enhance improved standard of living for himself and people around him. It is a step toward peace and happiness of all. Islam, on the other hand was instituted for man's terrestrial and celestial happiness. Its goal is peace for all - peace with oneself, peace with other creatures including animals and the environment, and above all, peace with God. All its laws are therefore designed towards achieving peace and tranquility for mankind. Beyond this, however, the religion also has, within its structure, mechanism for achieving this. This, which the modern man calls "planning" in all its guises and ramifications, is naturally embedded within the structure of Islam. The focus of this paper therefore, is to examine this mechanism for achieving this all important man's desired goal called "planning" as it subsists within the structure of Islam. This is with a view to showing the beauty of Islam as a religion which has within it all that man can think of on the one hand, and on the other hand, draws the attention of the world to its strategic plan for peace and development so as to tap it for the benefit of the human race. 


\section{Strategic Plan}

\section{CONCEPTUAL CLARIFICATIONS}

Plan simply means deciding in advance what to do, how to do it, when to do it and who is to do it. It is a necessary tool used by individuals, organizations and governments in setting goals and appropriate means of realizing them. In relation to government, strategic plan can be described as a comprehensive predetermination of a nation's visions, mission, polices and programmes in all facets of life such as economic, social, political, environmental, technological factors etc and means of achieving them. At the multi-national level, such a plan had been conceived and attempts were actually made to implement. These came under the names the Millennium Development Goals (MDGs) and later the Sustainable Development Goals (SDGs). The Millennium Development Goals (MDGs) were the eight-point agenda conceived and adopted by one hundred and eighty-nine (189) member states of the United Nations in collaboration with twenty-three (23) other international organizations in 2000 as imperative social needs and priorities of people worldwide to be addressed before 2015 (United Nations, 2012). The set of eight goals included eradication of extreme poverty and hunger, achieving universal primary education, promoting gender equality and empowering women, reducing child mortality, improving maternal health, combating HIV/AIDS, malaria and other diseases, ensuring environmental sustainability and developing global partnership for development. According to Sachs (2012), this global attempt to package these priorities into an easily understandable set of eight goals and establish measurable and time-bound objectives for them under the name MDGs help promote global awareness, political accountability, improved metrics, social feedback and public pressures for those needs. The relative successes in the attainment of these goals however, served as precursors for the inauguration of another 15-year Plan in 2014 envisioned in the Sustainable Development Goals (SDGs). The Sustainable Development Goals (SDGs) couched in seventeen (17) goals and one hundred and sixty-nine (169) targets are a proposed set of global priorities relating to the future international development. They replaced the Millennium Development Goals (MDGs) at the end of 2015. All these efforts, in technical terms are what is called strategic plan be it at the local, state, and national level and global level.

\section{Peace}

Peace describes a state of tranquility, quiet and harmony. It depicts an atmosphere that is free from of chaos, crisis or disturbance of any sort. A peaceful environment also describes a situation where there are no oppressive and unpleasant thoughts and emotions either in personal or communal relations. It portrays a state free from of uproar or war particularly between people of different ethnicity, language or religion. It describes a state of lack of conflict among the people. It need be noted however that the absence of war does not necessary indicate that there is peace. All indices must point to the fact that people are naturally happy and enjoy some kind of joy in their interaction with one another. There must be serenity and calm in the atmosphere to establish there is peace in a particular society.

\section{Development}

The World Bank (1994) defines development as improving standards of living over the long term. Gboyega as cited by Lawal and Abe (2011) describes it as "an idea that embodies all attempts to improve the conditions of human existence in all ramifications. The World Commission on Environment and Development (WCED), describes it as the development which meets the needs of the present without compromising the ability of future generations to meet their own needs" (Harris, 2000). In the words of Adebayo, "the bottom line of the concept is the efforts at improving the socio- economic and ecological status and at exploiting and processing the environment or natural resources for the purpose of improving the quality 
of human life in such a way that the needs of the future generations are not jeopardized" (2011). The United Nations Development Programme (UNDP) sees it as creating an environment in which people can develop their full potentials and lead productive, creative lives in accord with their need and interests. In Banjo's (2001) opinion, development is all about people. Development therefore is much more than economic growth which is only a means of enlarging these choices. Rather, it extends to having a populace who are not malnourished, illiterates or unemployed. Development therefore would mean having a well nourished and healthy people who are well educated and highly civilized and disciplined. It follows therefore that development means improvement not only in material well-being of all citizens in a sustainable way such that today's consumption does not imperil the future. It also demands that poverty and inequality of access to the good things of life be removed or drastically reduced. Thus, development is not only restricted to the concept of modernization, where supposedly, there is a chain of industries, good road networks, beautiful urban development etc but also seeks to improve personal physical security and livelihoods and expansion of life chances. Fundamental to enlarge these choices is building human capabilities. The most basic capabilities for human development are to lead long and healthy lives, to be knowledgeable, and to have access to the resources needed for decent standard of living, and to be able to participate in the life of the community.

Al-Qaradāwī (1995), in what he called 'necessity of plan' opines that for a nation to attain and sustain an overall development in term of socio-economic, political and as well as religious advancement, there is a great need for planning. He said:

It is inevitable to make a plan based on: accurate calculation and exact figures, profound knowledge of categories of peoples' wants and their place of priority, available capacity and easier means of having those wants satisfied as well as anticipation for aspirations (p.77)

This implies that a nation ought to identify its population and their needs according to their order of importance, available resources, strength and possible technical know-how as well as means accomplishing its goals and satisfying its needs. Al-Qaraḍāwī (1995) therefore opines as follows:

It is an obligation on the nation to collectedly monitor the plans and its implementation especially those put in the authority by Allah (p.78).

Thus, plan without implementation is as good as no plan at all.

\section{STRATEGIC PLAN FOR PEACE AND DEVELOPMENT IN ISLAM}

An eight-step strategic plan for peace and development of the society has been identified in Islam. Each of these is consequential of the other and all work together toward achieving this same goal - peace and development of the human society. Each of these steps is discussed below.

\section{The Five Pillars of Islam}

Traditionally, the fundamental rites/pillars of Islam are five. These are: i) to testify that there is no deity (owing the right to be worshipped) but God, Allah and that Muhammad is Allah's Messenger, ii) to offer (compulsory congregational) five daily prayers dutifully and perfectly, iii) to pay Zakat (i.e. obligatory charity), iv) to perform Hajj (i.e. Pilgrimage to Mecca), and, v) to observe fast during the month of Ramadan (Khan, n.d). Each of these pillars of Islam is aimed at societal peace and development. The first pillar of Islam for example, is "Testifying to the oneness of God". This is technically called the Kalimat ash-shahaadah. The one who claims to be a Muslim was expected to have pronounced the phrase: "Ashhadu 'an-La ilaha illa Allah wa 
ashhadu anna Muhammadan abduhu wa-Rasuluh". With these words which mean "I testify that there is no deity (owing the right to be worshipped) but Allah and that Muhammad is Allah's Messenger", he is welcome to the fold of Islam. Once those words were said by an individual, he is said to be a Muslim and is expected to forsake all other gods/things, material or metaphysical, human or spiritual that might have hitherto enjoyed his adoration and glorification. He should, henceforth, see and acknowledge the Lordship and Mastership of One Supreme Being called Allah in Arabic, as the only One worthy of his adoration and glorification. On the other hand, he should see himself as His creature and His servant- one who is ready to serve and obey Him. He should acknowledge the danger of incurring His wrath if he disobeys His Law. The actual import of the segment of this phrase is aptly explained by Pickthall when he writes:
...it is clear that the existence of a Supreme God, Allah, is assumed as an axiom common to Prophet Muhammad (be peace on him) and his opponents. The Qur'ān never argues the point; what it does argue is that He is the One and only God-La ilaha illa-Lah, there is no God but Allah and that God is the Omnipotent Master and man is His creature who is ever in danger of incurring His wrath if he disobeys the Law (Picktall, 1981, i)

Such a person must be able to differentiate between this God, and all others whose images and concepts were created by men desirous of name, wealth and authority. He must be able to distinguish between this God and the ones whose images or ideas were of human creation, imaginations and perceptions regardless of how popular that the idea or perception of that god is in his/her society and in any age. Such understanding of the God of Islam and the declaration of faith in Him will help the believer in seeing and acknowledging Him as the Fountain of all forms of success, power and glory, thereby ignoring ritualism, cultism and other forms of unionism in which people involve themselves in quest of power, success and other things and which often cause chaos in the society. It will also assist in building a healthy and drug-free society as such a professor of the unity of God will be free of hypertension, stroke, cardiac arrest and similar ailments emanating from greed for worldly materials. Hence, the people in the society individually and collectively enjoy its peace while the society in which such people live also experience an all round development. A perfect understanding and declaration of the Divine Unity of God therefore goes beyond the recognition that the world has only One Creator as it also has socio-economic, moral and developmental implications for the individual and the society.

The second pillar of Islam is the observance of the compulsory congregational five daily prayers dutifully and perfectly. This is technically called As-Salat. Qur'ān 20:14 (Surah Taha) says: "...serve me and establish Salah for my remembrance". Qur'ān 29:45 also says about the Muslim form of worship: "and establish regular prayers: for prayer restrains from shameful and evil deeds;... (Surat al 'Ankabuut). In Qur'ān 2: 45, Allah also says: Nay, seek (Allah's) help with patient perseverance and prayer, it is indeed hard, except to those who are humble". All these verses show, in a simple manner the role the Muslim form of worshipping the Supreme Being (As-Salat) plays in human society - restraining the worshipper from shameful and deeds as well as patiently persevering both of which ultimately enhance peace, tranquility and development in the society.

In a similar way, Zakat also enhances peace and development if its purpose in the society is considered. Qur'ān 9: 103 (Surah at-Tawbah) states: "take sadaqah (alms) from their wealth in order to purify them and sanctify them with it...". Qur'ān 9 verse 60 also explains: the sadaqah (compulsory alms) are for the poor and the needy and those employed to administer the (funds): for those whose hearts have been (recently) reconciled (to Truth); for those in 
bondage and in debt; in the cause of Allah; and for the wayfarer" so that "wealth does not circulate only among the rich". The idea of Islam is that if the poor sector of the economy is taken care of by the rich, societal peace and development will be guaranteed. This is done in two ways - one, the poor who benefit from the wealth of the rich will most likely not think of or be involved in evil deeds towards them and second, the poor are being assisted to live a life worthy of human beings. Consequently, an all round peace and development of the society is achieved.

The institution of fasting as a rite in Islam also has positive implications for societal peace and development. The Muslim Scripture has ordered the Muslims thus: "O you who believe! Fasting is prescribed to you as it was prescribed to those before you. That you may (learn) selfrestraint. (Qur'ān 2:183)". Siddiqi (1972) is of the opinion that of all the creation of God, only man deviates from His path on the ground of their love for material possession and the temptations of the flesh. While Zakah and Sadaqat are meant to modify man's love for material possession, Sawm (fasting) is meant, not to eradicate or undermine these temptations and low desires of the flesh but to keep them well within reasonable bounds so that man may not become their slave and lose control over himself. So, when the rich also fasts like the poor, feeling the pangs of hunger when, in actual fact nothing stops him from satisfying his lustful desires other than the fear of God and a feeling for the poor, the moral lessons of giving to those who have not as well as not looking down on them which the Muslim fast of Ramadan is meant to teach among other things will bring about peace and development in the society. Siddiqi (1972) writes further:

... (a) distinguishing feature of Islamic fasting is that it does not train a person for complete renunciation but for perfect and cheerful obedience to the Lord. All those things from which man is commanded to abstain during fast, e.g. eating, drinking and sexual intercourse, become permissible for him at the end of the fast. This shows that Islam does not look down upon the appetite of flesh as something ignoble and thus fit to be exterminated root and branch from the human soul. According to Islam, there is nothing profane or ignoble in human personality: both soul and body are sacred and worthy of respect. No aspect is to be ignored and no urge is to be completely curbed. What is required is to keep all these urges well within their proper limits so that none of them transgresses natural bounds and becomes the source of trouble ( $p$. 523).

Fasting, in Islam, is therefore the act of regulating man's urge such as that of eating, drinking, and sexual intercourse so that he will be a master over, rather than being a slave to them. This idea of self-restraint is a key to enhancing societal peace and development.

If one also looks at the significance behind the performance of Hajj (Holy Pilgrimage to Makkah), one will realize that hajj is also designed by God to bring about peace and tranquility in human society. The Almighty Allah said: "The First House (of worship) appointed for men was that at Bakka: full of blessing and of guidance for all the worlds. (Qur'ān 3:96). In another verse, He said: "And we covenanted with Abraham and Isma'il, that they should sanctify My House for those who compass it round, or use it as a retreat, or bow, or prostrate themselves (therein in prayer)" (Qur'ān 2:125). Again, Allah said: "O our Lord! I have made some of my offspring to dwell in a valley without cultivation, by Your Sacred House; in order, 0 our Lord, that they may establish regular prayer:... "(Qur'ān 14:37). From all of these, one can see that the institution of hajj is capable of enhancing peace and development of the society as the Kabah which is central to the performance of hajj is said to be "full of blessing and of guidance for all the worlds", and "those who compass it round use it as a retreat, bow, and prostrate themselves and as well establish therein regular prayer". Shariati (1981) captures it all when he sees Hajj as a yearly course of practical and theoretical teachings of the Islamic doctrine 
given to more than a million Muslim representatives from all over the world where they would learn, among other things, the importance of unity. He concludes:

With a reserve of knowledge and information, they could return to their countries and their individual lives to teach their community. As a result, all his life, a Hajj could remain a guide in the darkness of his society- like a glittering beam in the darkness (Shariati, n.d, p.viii)

Thus, all the pillars of Islam are instruments of societal peace and development if properly observed, used and their benefits well maximized.

\section{A Process of Repetition of the Pillars of Islam}

All the pillars of Islam listed and discussed above are what a Muslim is expected to uphold as basic to his religious life. They are so fundamental that defaulting in one when one is capable of undertaking it reduces the quality of one's belief, faith and commitment to that religion and the God behind it. Hence, it is said that people's faith in Islam can increase or decrease. The Qur'ān states this when it recounts the response of God to the position of the Arabs who, upon pronouncing the Kalimat ash-shahaadah, claimed that have attained a certain level of faith in God. The relevant portion of the Glorious Qur'ān reads:

The desert Arabs say: "we have faith". Say: "You have no faith yet but (only) say, 'we have submitted our wills to Allah, for faith has not yet entered your hearts. But if you obey Allah and His Messenger (S.A.W), He will not decrease anything in reward for your deeds. Verily, Allah is Oft-Forgiving Most Merciful (Qur'ān 49:14).

In an attempt to make these tenets of Islam part and parcel of the adherents so as to take maximum advantage of them including those relating to the subject of this study as individuals and as a people (i.e. in the society), Islam has also instituted a process of repeating those pillars of Islam. The process of repetition has been so made that it poses no threat or challenges to the one's daily life or career. While some are to be repeated five times a day, some are to be repeated once in a year and others once in a lifetime. The Kalimat ash-shahaadah, for example is to be pronounced once in a lifetime, a Muslim who gets him/herself involved in an act or acts capable of doubting his/her belief in (the ability of) that One Supreme Being, must necessarily repeat it before he can be regarded as a Muslim any further. Although, he is not expected to do this repeatedly as that will constitute unseriousness in matters of faith (Qur'ān 2: ), he /she is availed the opportunity of the advantages associated with it including those relating to peace and development of the society each time he/she says it. Besides, it constitutes one of the formulas recommended by the holy Prophet Muhammad (SAW) to be chanted for enhancing the pleasure of Allah in lieu of what the rich and the mighty could be doing for Allah's sake which the poor Muslim may not be opportune to do (Abdul, 1982). Thus, it has been part of the formulas Muslims recite in their Five daily prayers and in their supplications and each time the Muslim says this, whether to renew his faith (i.e. re-enter the fold of Islam) or with a mind to achieving the pleasure of God in lieu of what the rich and the mighty do or even as a formula in Salat or supplication, himself and the society takes full advantages of the purposes it serves including bringing peace and development to the society. Thus, the institution of the process of repeating this pillar of Islam is a step in the strategic plan of Islam in enhancing peace and development of the society.

In a similar vein, the observance of the canonical prayer five times daily also carries with it all the advantages that the Salat brings viz-a-viz peace and development of the society. The Qur'ān 
says: "...Set up regular Prayers: for such prayers are enjoined on believers at stated times". (Qur'ān 4:103). Again it says: "And establish regular prayers at the two ends of the day and at the approaches of the night... that is a reminder for the mindful" (Qur'ān 11:114). And also in Qur'ān 20:130: "And celebrate (constantly) the praises of your Lord, before the rising of the sun, and before its setting; yea, celebrate them for part of the hours of the night, and at the sides of the day: that you may be pleased". Thus, each time the Muslim observes the Salat, he/she is working for the peace and development of the society.

Zakat is also instituted annually in Islam. Each year the Muslims do this, the benefits of the poor not thinking of or doing evil to the rich because they have benefited from their wealth as well as those relating to the poor being assisted to live life worthy of human beings will keep on recycling peace and development in the society. When Ramadan fast is also observed annually, the feeling of the pangs of hunger which the rich feel when, in actual fact they have all it takes to satisfy their lustful desires but for the fear of God and the moral lessons of giving to those who do not as well as not looking down on them will make peace and development the property of the society. Hajj also gives the Muslim society peace and development, having provided a platform for a handful of Muslims selected across the world to be taken through the "dos" and "don'ts" of God during the course of the pilgrimage and to return to their various communities and live as examples and models for other people in the society. Each year this is done, the society is permeated with peace and development. Thus, the process of repeating each of the pillars of Islam is a strategy that the religion has adopted to enhance peace and development of the society.

\section{Institution of "Dos" and "Don'ts"}

According to the Encyclopedia Britannica, every religion has rituals to perform, formulas to recite, tales to narrate, objects to manipulate, places to frequent or avoid, holy days to keep, natural phenomena by which to predict the future, charismatic leaders to follow truth to affirm, a literature to ponder and precepts to obey. Islam is no exception to these. It has a list of "dos" and "don'ts" codified into the legal component of its value system called the Shari'ah. A number of the verses of its Holy Book (i.e The Qur'ān) which is the basis of its tenets as well as the Hadith in which the life and activities of its leader (i.e. Prophet Muhammad) were codified specify these. Qur'ān Chapter 17(Surat al 'Israil) verses 22-37, for example, list a number of these "dos" and "don'ts" thus:

Take not with God another object of worship lest you remain debased and forsaken. Your Lord has enjoined you to worship none but Him and to be good to parents. If either or both attain old age (while living) with you, never say to them, "fie" (or any word expressive of disgust or dislike), nor reproach them (by your action). Rather address them with kind and respectful words (always). And lower to them the wings of submissiveness out of tenderness (treating them with humility and compassion). And say (praying for them), "My Lord! Have mercy upon them just as they nourished and brought me up as a child". Your Lord knows very well what is in your minds. If (He will find that) you are righteous, surely, He is a great Protector of those who turn to Him (for forgiveness) again and again. And give to the near of kin and needy, and the wayfarer their dues, and do not squander (your wealth) wastefully. Certainly, the squanderers are like satans and Satan is always ungrateful to his Lord. If you have to turn away from them seeking the mercy from your Lord that you hope for, even then speak to them a kind word. And do not keep your hand shackled to your neck (out of miserliness), nor stretch it out to an entire stretching (extravagantly), lest you sit down reproached (incurring blame) and exhausted (on becoming penniless). Surely, your Lord multiplies His provisions and means of livelihood for such of His people as 
He will and He measures it out (justly), for He is Well-Aware and Seeing of (the true needs of) His people inside out.

The Qur'ānic passage continues:

And do not kill your children for fear of want. It is We Who provide for them as well as for you. Indeed, the killing of them is a great sin. And keep away from adultery and fornication; surely, it is an abominable act, and an (extremely) evil practice. And do not kill anyone, the sanctity of which Allah has upheld (and has forbidden you to slay) except for a just cause. And We have given, of course, to the heir of the person who is killed unjustly the right (to demand retribution or to forgive). But let him not exceed the (prescribed) limits in killing (the murderer) because he is indeed helped (and protected by law). And go not near (to utilize) the property of an orphan, except in the fairest manner and intention (in favour of the orphan) until he attains his (age of) full strength, (when the property is to be returned to him), and fulfill (your) agreements, for (every) agreement is certainly questioned about and has to be accounted for. And give full measure when you measure out, and weigh with a right (and even) balance. That is best and most commendable in the long run. And do not follow and utter that of which you have no knowledge. Surely, the ear and eye and the heart, all of these, shall be called upon to account (for it). And do not walk haughtily in the land, for you cannot (thus) rend earth asunder, nor can you match the mountains in height.

Verse 38 of the same chapter then concludes: "All those bad behaviours (listed above) are hateful to your Lord".

Such are the instructions of the Glorious Qur'ān to Muslims. They spell out in clear terms what the adherents should do and should not do. A careful consideration of these maxims clearly shows that they are aimed at enhancing societal peace and development. For example, the instruction to deal gently with ones' aged parent will enhance peace within the family just as ordering giving to the kindred, the needy, and the wayfarer is also capable of fostering societal peace because envy and rancor will be unimaginable from them having been cared for by the ones who have among them. Part of the instructions is also to the effect that Muslims should not squander their wealth wastefully but rather spend it wisely so as not to "sit down reproached incurring blame and exhausted on becoming penniless". The instruction not to kill one's children or any other soul as well as those prohibiting sexual immoralities and usurping of orphan's property are all also geared towards good inter-personal and family relations capable of societal peace and development. All these instructions, if kept and observed will bring about peace in the society as cases of suicide (arising from bankruptcy), abortion (arising from infanticide and sexual immoralities) murder (which may arise from injustice of usurping the orphan's property) will be unheard of in the society. In a similar vein, the instructions to fulfill promises and agreements, and to give full measure and right weigh are all also geared towards societal peace and development as all forms of rancor and possible assassination arising from crises associated with such issues will be non-existent in the society. There is also an instruction to the effect that Muslims should not carry rumours or bear false witness. The appropriate portion of the Qur'ānic passage states: "And do not follow and utter that of which you have no knowledge". This also prevents social crisis in the society and consequently brings about peace and development of the society. Hence, the passage of the Qur'ann ends with the sentence: "That is best and most commendable in the long run".

\section{Attachment of Reward and Punishment to the "Dos" and "Don'ts"}

In order to ensure compliance to the instructions of the "dos" and "don'ts" so as to ensure that individuals and the society take full advantage of the benefits accruable from them including 
achieving peace and development in the society, Islam has also attached rewards and punishments to those dos and don'ts. It promises those who observe the "dos" and "don'ts" paradise while those who fail to observe them are promised a lifetime in hellfire. In Qur'ān 4: 124 for example, Allah said:

If any do deeds of righteousness, be they male or female- and have faith, they will enter Heaven, and not the least injustice will be done to them

And in Qur'ān 32:20, Allah said:

As to those who are rebellious and wicked, their abode will be the Fire; every time they wish to get away therefrom, they will be forced thereinto, and it will be said to them: "Taste ye the penalty of the Fire, that which you rejected as false.

In order to show the seriousness attached to the concept of punishment and reward, the Qur'ân stipulates that certain offences should be punished in this world while others would be punished in the hereafter. The Qur'ān for example says regarding adultery:

The woman and the man guilty of adultery or fornication, flog each of them with a hundred stripes (Qur'ān 24:2).

Regarding false witness, the Holy Book of Islam also says:

Those who launch a charge against chaste women, and produce not four witnesses (to support their allegations), flog them with eighty stripes and reject their evidence ever after; for such men are wicked transgressors unless they repent thereafter and mend their conduct...(Qur'ān 24:4)

For those who cause disorder (such as armed robbery, terrorism, etc) on the surface of the earth, the Qur'ân stipulates the following categories of punishment depending on the degree of crime and the level of involvement:

...We ordained for the children of Israel (i.e humankind) that if any slew a person unless it be for murder or for spreading mischief in the land - it would be as if he slew the whole people and if any one saved a life, it would be as if he saved the life of the whole people. Then, although there came to them clear signs, yet, even after that many of them continued to commit excesses in the land. The punishment of those who wage war against God and His Apostle and strive with might and main for mischief through the land is: execution or crucifixion or the cutting off of hands and feet from opposite sides or exile from the land (Qur'ān 5:30-33)

Apart from all of these, the Qur'ān also posits that, in giving these punishments, no mercy or compassion should be shown to them. The actual words of the Qur'ān here are:

Let not compassion move you in their case, in a matter prescribed by God, if you believe in God and the Last Day (Qur'ān 24: 2)

The Qur'ān also stipulates that a group of Muslims should witness their punishment perhaps as a way serving as witnesses that the punishment was meted out on them on the one hand and on the other, to create a sense of guilt and shame in them so as not to do such again. The Qur'ān says: "And let a party of the believers witness their punishment" (Qur'ān 24:2). Thus, the sense of reward and punishment attached to the "dos" and "don'ts" in Islam will surely be a factor in the attainment of peace and development in the society.

\section{Constituting a Common Front for Righteousness and Against Evil}

Another instrument of strategy planning towards achieving peace and development of the society in Islam is for the Muslims to constitute a common front for that purpose. The Qur'ān 
urges all Muslims to unite against all forms of vices which it has put together as don'ts and to also come together to encourage all forms of virtues i.e. dos. It says:

Help ye one another in righteousness and piety, but help ye not one another in sin and rancor (Qur'ān 5:3)

In a similar and more direct sense, the Qur'ān orders Muslims to come together in bringing about peace and development in the society when it says;

If two parties among the believers fall into a quarrel, make ye peace between them, but if one of them transgresses beyond bounds against the other, then fight ye (all) against the one that transgresses until it complies with the command of God. But if it complies, then make peace between them with justice, and be fair; for God loves those who are fair (and just) (Qur'ān 49:9)

Thus, there cannot be more direct instructions to achieving peace and development in the society that the above.

\section{Appointment of Good Leaders}

In order to achieve peace and development in the society, the religion of Islam has also insisted that a good government that would ensure compliance with the foregoing instructions be put in place. The religion has stipulated that though people have always felt the need to have a government and have also constituted governments of various components and natures, oligarchy, military, unicameral or bicameral democracy, what is important is to have one that would make peace and development of the society its goal. Hence, from the perspective of Islam, what the name of the system of government being run in a community or society is does not matter. What matters, however, is what it sets to achieve and what it is actually achievable with it and this must be nothing other than peace and development of the peace and the society. And for as long as this is and remains its objective, it may not need instructions, laws and directives other than those highlighted above. Hence, the Qur'ān says:

Therefore, fear not men, but fear Me, and sell not My words for a miserable price. If any do fail to judge by (the light of) what God has revealed, they are (no better than) unbelievers.... (Indeed), they are wrong doers (Qur'ān 4:47\&48.

However, both the leaders and the led are to come together to ensure that the laws are well implemented. Both of them would receive the blame of none or improper implementation of these laws. This is because the relationship between them is reciprocal as understood from Qur'ān 5:49 which reads:

Oh you who believe, obey Allah, obey the Messenger and those in position of authority among you.

And if the leaders failed to provide a conducive atmosphere for the citizenry to thrive and work for the peace and development of the society, then the leaders would receive appropriate sanctions from God Almighty. The Qur'ān indicates this when it says:

And they would say: Oh Lord, we obeyed our chiefs and our great ones (as You directed) but they misled us. Our Lord, give them double penalty and curse them with great curse (Qur'ān 33:67-68)

However, Islam allows that erring leaders be deposed when the Qur'ān says:

And why should you not fight in the cause of God and of those who, being weak, are illtreated (and oppressed)? - men, women, and children, whose cry is : "Our Lord, rescue us from this town, whose people are oppressors, and raise for us from Thee one who will protect, and raise for us from Thee one who will help". Those who believe fight in 
the cause of God and those who reject Faith fight in the cause of Evil. So fight ye against the friends of Satan; feeble minded is the cunning of Satan (Qur'ān 4:75\&76)

The Qur'ān also says:

And fight them on until there is no more tumult or oppression and there prevails justice and faith in God ... (Qur'ān 2:193)

So, it is the responsibility of the citizenry to fight oppression and bad leadership. This from the perspective of Islam constitutes a great jihad. Failure to do this would mean that the citizenry too are guilty of conspiracy and this according to the Qur'ān also attracts God's wrath which is manifested in punishment in hellfire. The Qur'ān quoted the citizenry as going to argue thus:

Our Lord, it was these (people) who misled us, so give them a double punishment in the fire. He (Allah will say: "Double for all..." Then, the first (group) will say to the last (group), "See then! No advantage have you over us, so taste ye of the penalty for all that you did) (Qur'ān 7:38-39)

Thus, from the foregoing, it is clear that the demand for good leader and good followership by Islam irrespective of the name the government being run bears is a strategic plan for achieving peace and development of the society.

\section{A Sense of Accountability/Day of Judgement}

Islam has also made belief in the Day of Jugdement a concept in the religion. In fact, it is an article of faith. This means that every Muslim must belief that a day will come when he/she will be call to account for all his/her deeds. According to Islam, two angels, Munkar and Nakir accompany every human being to wherever he/she goes and in whatever he/she does. They take account of all that man does and tender these as evidence against him/her on the day of jugdement. The Qur'ān alludes to that thus:

Behold, two (guardian angels) appointed to learn (his doings) learn (and note them), one sitting on the right and one on the left. Not a word does he utter but there is a sentinel by him, ready to (note it). And the stupor of death will bring truth (before his eyes): "This was the thing which you were trying to escape (Qur'ān 50:17-19)

On that day, the Qur'ān also posits that man shall be rewarded according to the records provided against him/her and no act of injustice shall be meted against anyone; rather each person shall be rewarded according to what he did right or wrong in this world. The Qur'ān says:

We shall set up scales of justice for the Day of Jugdement, so that not a soul will be dealt with unjustly in the least. And if there be (no more than) the weight of a mustard seed, We will bring (to account); and enough are We to take account (Qur'ān 21:47).

It continues:

If any do good, good will (accrue) to them therefrom and they will be secure from the terror that Day. And if any do evil, their faces will be thrown headlong into the Fire: "Do you receive a reward other than that which you have earned by your deeds (Qur'ān 27:89\&90)

Belief in a day like this as Islam requires its adherents to do will naturally make people do righteous deeds which in turn will bring about peace and development in the society 


\section{Supplication (Du'a)}

Islam generally urges Muslims to offer supplications for the peace of the society. In a number of Qur'ānic verses, Muslims are enjoined to offer prayer for themselves, members of their families and the society in general with a promise that the God the worship listens, hears and answers their supplication (Qur'ān 27:62, Qur'ān 42:26, Qur'ān 55:29, Qur'ān 2:186 etc). Specifically, however, they are also urged to supplicate against any insinuation that may lead to discord in the society. Qur'ān 41:36 says:

And if (at any time) an incitement to discord is made to thee by the Evil one, seek refuge in God; He is the one who hears and knows all things.

Specific formulas are also offered for this purpose. This is found in the muwizzatayn (i.e chapters $113 \& 114$ of the Glorious Qur'ān. Thus, Islam seeks to enhance the peace of the society through supplication (du'a) and when and where there is peace, there is bound to be development.

\section{CONCLUSION}

From the foregoing, it can be deduced that Islam is not only a way of life that it claims to be but also has within its structure a mechanism for making man happy and also the society a peaceful place to live. Its eight step strategic plan for societal peace and development is natural and in tandem with human nature and therefore not difficult to implement. It is also cost effective as it requires no huge sums of money like other strategic plans either at the local, state, national and international level which are often not achievable for lack of will and lack of fund. The Islamic strategic plan requires no special fund, training or commitment on the part of the implementers. All it requires is for all to submit to the will of God in the way Islam has suggested and then stand by their submission by way of obedience. It will therefore be an understatement to say that the whole world will be at peace if the above eight step strategic plan of Islam is vigorously pursued and faithfully implemented by world leaders and organizations as all that the world desires in peaceful coexistence and overall development are achievable with it. All it requires is the will to swallow the bitter truth that the solution to the world crisis lies in the religion that has all along been blamed for the crisis itself.

\section{References}

Al- Qaraḍāwī, Y.A. (1995) Dawru'l-Qiyam wa'l-'Akhlāq fi 'Iqtisādi'l-Islāmi, (Cairo: Wahbah Publisher,

Abdul, M.O.A (1982) The Selected Traditions of Ai-Nawawi: Arabic Texts, Transliteration, Translation and Commentary, Book 4, Lagos: Islamic Publications Bureau

Adebayo, R.I. (2011) 'A Study of Some Factors Contending with Sustainable Development in Nigeria: A Muslim Perspective' in Culture, Science and Sustainable Development in Africa, ed K. Opoku-Agyemang, (Ghana: the University Press, University of Cape Coast,), 207.

Amoke E (2008) 'Human Resources Development and the challenges sustainable Development in Nigeria, Journal of Social Policy and Society, 3, no. 3, 99-101

Banjo A (2001) "Some Humanistic Perspectives on the Nigerian Condition" in Agwonorobo E. Eruvbetine (ed.) The Humanistic Management of Pluralism: A Formula for Development in Nigeria, Lagos: Murtab Press

Danjibo N. D (2012) “Democracy and Development: Evaluating Nigeria's Social Indicators, 1999-2010”, in Albert O. I, Eselebor W A and Danjibo N. D (eds.) Peace, Security and Development in Nigeria Institutte of African Studies, University of Ibadan and Society for Peace Studies and Practice, Abuja, pp. 49-71

Lawal T and Abe Oluwatoyin, (2011) 'National Development in Nigeria: Issues, Challenges and Prospects' Journal of Public Administration and Policy Research, 3, no. 9,: 237-238.

Harris, M.J. (2000) Basic Principles of Sustainable Development, (USA: Global Development and Environment Institute, Tufts University,: 5

Khan, M.M. (n.d) The Translation of the Meaning of Sahih Al-Bukhari, Vol. 1. Beirut: Dar Al-Arabia, 
Pickthall, M (1981) Quranic Advices, Lagos: Islamic Publications Bureau, preface page.

Sachs J (2012) End of Poverty, New York: The Penguin PressS

Shariati, A (n.d) Hajj,Lagos: Islamic Publications Bureau

Siddiqi, A. (1972), Sahih Muslim, Vol.1, Beirut: Dar Al-Arabia.

United Nations (2012) GEO5: Global Environment Outlook - Environment for the future we want, Nairobi, http://www.unep.org/geo/pdfs/geo5/GE05_report_en.pdf

World Bank (1994) Adjustment in Africa: Reforms, Results and the Road Ahead, Washington:, D.C World Bank 